\title{
Significance of Varanasi in terms of Indian religions
}

\author{
Cemil Kutlutürk \\ 1(Department of World's Religion, Faculty of Divinity, Ankara University, Turkey)
}

\begin{abstract}
Varanasi has a significant universal value and spiritual quality, on account of its architectural heritage is linked strongly, since centuries, to the living cultural and religious traditions of three of the major religions of the world which are Hinduism, Buddhism and Jainism. According to their followers the city is one of the most important religious pilgrimage destinations. Even today traditional worship, religious rituals, beliefs and festivals are still practiced in here. While Varanasi is predominately associated with Hinduism, strong ties to Buddhism and Jainism also exist in this region. This paper, therefore, targets to mention about significance of Varanasi in terms of Indian religions, respectively, and informs about major holy sites such as River Gangas, Kashi Vishwanath Temple, Sarnath and Bachraj Ghat also known as Jain Ghat which are related to Indian Religions. This article, on the other hand, aims to demonstrate that why this old city is regarded as holy by individuals who belong to different Indian religions.
\end{abstract}

Keywords: Holy site, Indian religions, Sarnath, Varanasi (Banaras)

\section{Introduction}

India is a nation that believes in the ideology of unity in diversity. It is an abode to different religions, cultures, traditions, ethnic values and customs. A vast majority of Indians associate themselves with a religion. Religion, therefore, has been an important part of the India's culture and tradition, throughout its history. In spite of the fact that over 78\% of India's population practices Hinduism; Islam, Christianity, Sikhism, Buddhism and Jainism are the other major religions in India. [1]

India is the birthplace of Hinduism, Jainism and Buddhism which are the three major Indian religions. It can be found various holy sites in different parts of this country but, especially, Varanasi has the main sacred places with regards to Indian religions. The city is the mosaic of Indian culture with respect to representing the diversity and the distinctiveness of the regional cultures of India. People from different parts of India, speaking different languages and carrying their own features, beliefs and customs have settled in this city. But in this process they inwardly have protected their own culture and outwardly have become a part of mosaic culture of the city. Varanasi, thence, is a living expression of Indian culture and traditions in all its multi-ethnic traditions, ancient educational methods and practices, religious beliefs and rituals architectural treasures and sacred places. [2]

Varanasi, the holy city of India, is also known by the name of Banaras and Kashi. The name Varanasi has its origin possibly from the names of the two rivers Varuna and Assi for the old city lies in the north shores of the Ganges bounded by its two tributaries, namely Varuna and Assi.[3] The word "banaras", on the other hand, comes from the word "bana" which means "a place where always ready" and the word "ras" which means "juice of life". It is the blending of these two words, which makes up the mosaic of culture known as Banaras. The sacred of place, the continuity of cultural traditions and the natural setting have all blended together to create and maintain a unique lifestyle known as Banarasi. [4] The city, furthermore, is an extraordinary testimony to living traditions in religious faith, rituals and various festivals, ancient forms of worship and belief that are still practised, passing from one to other generations, from past to present.

This city has an important worth particularly for three major Indian religions which are Hinduism, Buddhism and Jainism due to its historical and sacred places of such religions. It is also assumed to be a storehouse of religious ceremonies and festivals most of them are performed in holy places or temples. [5] There are few cities in the world of greater antiquity and none have so uninterruptedly maintained their ancient distinction and reputation. In this sense, analyzing of Varanasi city by approaching its holy sites has a special meaning in the way of understanding of Indian religions properly.

\section{Significance Of Varanasi According To Hinduism}

Varanasi is a holy city for Indian religions especially for Hinduism and being one of the most sacred pilgrimage places for Hindus of all denominations. Banaras is to Hindus what Mecca is to Muslims or Vatican to Catholics. Because the holy sites such as Ganges River Gangas, Ghats, and Kashi Vishwanath Temple are situated in this city. On the other hand, it is one of seven Hindu holiest cities (Sapta Puri), considered the 
provider of salvation (moksha). Varanasi also houses a community of more than 50,000 Brahmins who supply religious services to devout. Moreover, the holy epic poem Shri Ramcharitmanas by Goswami Tulsidas was also written here. [6] All these kinds of grounds make Varanasi a significantly holy place.

It is the sacred city of the Hindus and is situated at the banks of river Ganga. The antiquity of the city dates back to the palmy days of Shaivism; for it is a city sacred to Shiva who is believed to have made it his permanent abode. When Shaivism reached zenith of its glory, the city became the leading centre of Hindu culture and learning. The number of temples in Varanasi is computed to be over 3000 and idols half a million. Most of the temples are ascribed to God Shiva who is accepted as destroyer and the members of his family.

A place most sacred to the Shiva is the Jnana-Vapi, the well of knowledge in which Shiva is believed to have taken refuge when the temples were destroyed. A bath in the waters of Manikarnika well of the temple is supposed to clean the body and the soul. The city typically represents Hinduism in all its phases. Alongside centres of culture, in which abstract forms of thought are almost scientifically analysed, there exists gross faiths and superstition. [7]

In Varanasi it can be found over 3000 Hindu shrines and temples most of them are dedicated to Shiva and the members of his family. The chief of the existing temples in Varanasi is the Vishwanath temple dedicated to Shiva. It is perhaps the most famous temple in Varanasi and located on the outskirts of the Ganges. The name of Vishwanath means "Lord of the world". Besides this temple, in Banaras there are two other significant temples named "Durga". The first one is Durga Mandir which built about 500 years ago and other one is Durga Kund which built in the 18th century. Thousands of Hindu devotees visit Durga Kund during "Navratri" to worship the goddess Durga. The temple has multi-tiered spires and is stained red with ochre, representing the red colour of Durga. The building has a rectangular tank of water called the Durga Kund. Every year on the occasion of Nag Panchami, the act of depicting the god Vishnu reclining on the serpent Shesha is recreated in the Kund. [8]

On the other side, the city owes its existence, especially, to the Ganges River considered to be the most holy river for the Hindu people and particularly sacred in Varanasi where its course towards the Bay of Bengal suddenly turns north. Symbolically, the flow from south to north refers to the life cycle from death. This unique directional change of the river course leads to development of the significance of the ancient city. [9]

The Ganges is the most sacred river to Hindus and is also a lifeline to millions of Indians who live along its course and depend on it for their daily needs. It is worshiped as the goddess Ganga in Hinduism. [10] Hindus postulate that the waters of the Ganges to be both pure and purifying. Nothing reclaims order from disorder more than the waters of the Ganges. Moving water, as in a river, is assumed purifying in Hindu culture because it is thought to both absorb impurities and take them away. [11]

Most of Hindus bathe in Ganges's water, over the course of river. Throughout her course, they pay homage to their ancestors and to their gods by cupping her water in their hands, lifting it and letting it fall back into her; they offer flowers and rose petals. On the journey back home from the Ganges, they carry small quantities of her water with them for use in rituals. When a loved one dies, they return to the Ganges to consign the ashes to her custody. The Ganges is invoked whenever water is used in Hindu ritual, and is therefore present in all sacred waters. [12] Varanasi, besides this, is a holy city for Hindus because of its historical ghats. It has at least 84 ghats which are embankments made in steps of stone slabs along the river bank where pilgrims perform ritual ablutions. Steps in the ghats lead to the banks of River Ganges, including the Dashashwamedh Ghat, the Manikarnika Ghat, the Panchganga Ghat and the Harishchandra Ghat where Hindus cremate their dead. Many ghats are linked with some legends and most of them have their own qualities. For instance The Tulsi Ghat is famous for its association with the poet Tulsidas (C.E 1547-1623). The Asi Ghat, situated in the south at the union of the rivers Ganga and Asi is significant for the Surya Shashthhi festival. The Ganga Mahal Ghat is an extension of the Asi Ghat, and includes a palace built by the Maharaja of Benaras in 1830. The King of Rivan's palace stands at the Rivan Ghat, another extension of the Asi Ghat. Beside this, the Dashashwamedh Ghat is the main and probably the oldest ghat of Varansi located on the Ganges. It is believed that the god Brahma created it to welcome Shiva and he also sacrificed ten horses which were performed here. [13]

Devout Hindus who complete pilgrimages to the region believe that by bathing in the Ganges River, God will help in wiping clean any mental or emotional impurities as well as results in the remission of sins. It is also accepted in the Hindu faith that by dying in the city of Varanasi, a soul can effectively bypass the reincarnation process. [14] The idea behind this belief is that Varanasi is so holy, that any soul who leaves a body in its borders is naturally pure enough to enter the afterlife without the purification process of rebirth. Every devout Hindu, therefore, wishes to visit the city once in a lifetime and hopes to die there in old age. That is why more than a million pilgrims visit this sacred city each year. 


\section{Significance Of Varanasi According To Buddhism}

Even though Varanasi is predominately associated with Hinduism, important holy sites which are related to Buddhism also are available in the area. For instance, a large park, called Sarnath, which is located 13 kilometers north-east of the city, is thought to be the original site for the beginning of Buddhism. It is believed that Sarnath is the site where Gautama Buddha taught his first lecture on the guiding doctrines of Buddhism, by followers of this philosophy. After describing the goals of the philosophy, He declared the park as a pilgrimage site. [15] Following this announcement, Buddhist pilgrims flock annually to the area, in hopes of carrying out their religious duties in the best way.

According to Buddhist tradition, after obtaining enlightenment at Bodh Gaya the Buddha came to Sarnath; and it was here that he preached his first discourse in the deer park to set in motion the "Wheel of the Dharma". Since this place the stream of the Buddha's teaching first flowed, it is one of the most holy sites for Buddhists. In Pali, Sarnath was known as "Isipatana", which means the place where holy men landed. Isipatana is mentioned by the Buddha as one of the four places of pilgrimage which his devout followers should visit, if they wanted to visit a place for that purpose. According to tradition The Buddha went from Bodhgaya to Sarnath about 5 weeks after his enlightenment. Before Gautama (the Buddha-to-be) obtained enlightenment, he abandoned his austere penances and his friends, left him and went to Isipatana

After attaining Enlightenment the Buddha, travelled to the Isipatana to enter into and preach to them. Firstly he went to his friends since he had seen that his five former companions would be able to understand Dharma easily. While travelling to Sarnath, Gautama Buddha had to cross the Ganges. According to legend, having no money with which to pay the ferryman, he crossed the Ganges through the air. When Gautama Buddha found his five former friends, he taught them, they comprehended and as a result they also became enlightened. At that time the Sangha, the community of the enlightened ones, was establlished. The sermon Buddha preached to the five monks was his first sermon, called the Dhammacakkappavattana Sutta. When the Sangha had grown to 60 in number, then Buddha sent them out in all directions to travel alone and preach the basic tenets of Buddha's philosophy, Dharma. [16]

In Sarnath several historical and holy structure and their ruins are present. Among them the Dhamekha Stupa is the most conspicuous construction at Sarnath. Dhamekha seems to be a distorted form of Dharma Chakra which means turning the wheel of the Dharma. The original stupa was constructed by Ashoka. The present size of the stupa is approximate, $31.3 \mathrm{~m}$ high and $28.3 \mathrm{~m}$ in diameter. The lower portion of the stupa is covered completely with beautifully carved stones. The Buddha gave the first discourse of his Dhamma and the eight-fold path at a deer park in Sarnath. That spot is marked by the Dhammeka Stupa, a solid, cylindrical, brick structure. The original foundations laid by the Emperor Ashoka in 249 BCE are still intact, though the stupa itself was re-built in the 5th century and has seen modifications and additions from time to time. On the other hand, it is said that originally there were to great stupas which adorned the city only the Dhamekha remained which is of the 6th century. [17]

The Dhamekha stupa is considered to be the holy place where the voice of Buddhism was first heard. Most of Buddhists, who are from different parts of world, visit this place orderly for circumambulation of this sacred stupa and to worship the Buddha. Some of them, particularly Tibetan Buddhists, repeat a mantra which is "om mani padme hum" when they circle of this structure.

According to inscriptions, there has always been a community of Buddhist monks in Sarnath from 200 BCE onwards. Sarnath reaches great heights during the Ashoka (273-232 BCE) and Gupta (400-600 CE) periods. The latter period saw an explosion in the spread of Buddhism as well as creativity in the arts. About 3,000 monks used to live in monasteries near the Dhammeka Stupa during the Gupta period. But nowadays, the original monastery is no longer standing and only its ruins remain today. [18]

At Sarnath, moreover, it can be found various ruins of ancient Buddhist monasteries as well as temples constructed by the Chinese, Burmese and Tibetan Buddhists and by the Maha Bodhi Society, with each one of them reflecting the architectural style of that country. One of the more well-known ones is the Mulagandhakuti Vihara built by the Sri Lankan Mahabodhi Society. This temple was built in 1931 and enshrines Buddha's relics found in Taxila, and which are displayed every year on Karthik Purnima. The walls of this temple have frescoes depicting the life of the Buddha, which were done over a 3 years from 1932-1935 by a Japanese artist. [19] The followers of Budhist Philosophy, annually, come to these kinds of historical and religious sites from all over the world to visit them and to commemorate the original lecture of Gautama Buddha.

\section{Significance Of Varanasi According To Jainism}

Jainism is one of the oldest religions identified today. It's not just a religion; it's thought way to live a happy life. Its principals, way of life and philosophies emphasize the essential of self-effort to progress the soul towards heavenly realization and freedom. Accaording to Jain tradition there are several holy sites in different parts of India. Among them Varanasi has a special place and importance. For Jainists, the historical significance 
of the region mainly draws from the belief that it is the birthplace of Parshvanatha, an important figure in the religion.

The Jain literature mentions to Varanasi as a Jain holy place since here were born 4 of the Jain Tirthankaras (the ford-makers). In the 8th century BCE Parshvanatha was born around Bhelupur in Varanasi. He was followed in the 6th century BCE by Mahavira, who also visited Varanasi during his 42nd year of teaching. The birthplace of Suparshvanatha, the 7th Tirthankara, is also referred in the Jain literature, but its location and identification have still not been confirmed. It is accepted that the present Jain temple in Sarnath, near the Dhamekha Stupa, was constructed to commemorate the birthplace of 11th Tirthankara, Shreyamshanatha. The birthplace of the 8th Tirthankara Chandraprabhu, is associated with Chandravati, an ancient village near the Varanasi. [20]

The region of Sarnath, which is near the Varanasi, also features Jain sacred places such as Digambara Jain Temple, Singhpura - Southwest of the Dhamekh Stupa. This Jain temple was built in 1824. According to belief, this is where Shreyanshnath, the 11th Jain tirthankara, was born. Therefore, Sarnath is not only significant in terms of Buddhism but also has an important value from the point of view of Jain tradition.

There are also different sacred sites for Jains in this old city. Bachraj Ghat, for instance, also known as Jain ghat, is a holy place for the Jain community for it is close to the birthplace of the seventh Jain Tirthankara which is located at the bank of the Ganga. Near this Ghat there are three Jain temples situated on bank of Ganges. It is assumed that visiting to these temples is a lifetime experience for Jain Pilgrim. Jain community people have a visit this place and have a dip in the Ganga and then go for prayers one by one in all the three consecrated temples. Varanasi, hence, is a pilgrimage site for Jains along with Hindus and Buddhists. It is believed to be the birthplace of Suparshvanath, Shreyansanath, and Parshva, who are respectively the seventh, eleventh, and twenty-third Jain Tirthankars. Furthermore, Shree Parshvanath Digambar Jain Tirth Kshetra (Digambar Jain Temple) which has a great religious significance according to Jain Religion, is situated in Varanasi. [21] On account of all such kinds of components the city is regarded as holy by Jain tradition.

\section{Conclusion}

The existence of several holy sites and religious beliefs which are different from each other demonstrate that individuals who have lived in this city can perform their religious doctrines and can visit their sacred places without any oppression and invasion for centuries. People, in general, respect to all kind of beliefs and allow living a person's inner life in this city. The majority of the people in the city are of the Hindus, yet religious tolerance is the norm in this city where various faiths and cults are believed in and different languages are spoken.

Holy sites, on the other hand, contribute to establishment of religious tolerance between individuals. In other words by means of observing religious and holy sites, people from different belief, culture and society can obtain a chance through which they can perceive several religious traditions. Individuals, thereby, enhance religious tolerance to all kinds of beliefs. By the way of religious indulgence a person acknowledges religious beliefs and practices which disagree with his own way of life. Moreover he accepts that others have the right to hold and practice their beliefs. [22] Another significant benefit of religious indulgence is, within a nation or ethnic group, acceptance of the right to hold beliefs that differ from the dominant religion, worship freely according to these beliefs and attempt to peacefully convince others to convert to that faith. In this sense, Varanasi, which is called the religious capital of India, is one of the most suitable samples of city of religious tolerance where a great deal of cultures and religious systems has been living since centuries.

Consequently, sacred places have a sacred purpose such as to gather people together, to constitute a community, to enable individuals to pray, worship and meditate together. Due do fact that people imbue some particular places with certain holiness, it is said that "sacredness or holiness" comes from the people. There is, in other words, a very human as well as a divine story to be told about such places. Therefore, such holy sites have a significant role in daily lifes of devotees. These kinds of holy sites, thus, should be known and acknowledged in order to make sense of people's conducts in a correct way.

\section{References}

[1] Peter Heehs, Indian religions: A historical reader of spiritual expression and experience (New York, New York University Press, 2002), p. 7; J. R. Sachar, Social, economic and educational status of the muslim community of India (New Delhi, Cirrus Graphics Pvt. Ltd., 2006), p. 28.

[2] Rana P.B. Singh and Dar V., Varanasi as heritage city (India) on the scale the UNESCO world heritage list: From contestation to conservation. International Conference on Communication for Development in the Information Age: Extending the Benefits of Technology for All, Varanasi, BHU, 2003, 1-11.

[3] Wilbert M. Gesler and Margaret Pierce, Hindu Varanasi, The Geographical Review, 90 (2), 2000, 222-237.

[4] Rana P.B. Singh, Cultural landscapes and lifeworld. literary images of Banaras (Varanasi, Indica Books, 2004), p. 10.

[5] Niels Gutschow, Benares: The sacred landscape of Varanasi (Axel Menges, 2006).

[6] Myra Shackley, Managing sacred sites: Service provision and visitor experience (Cengage Learning, 2001), p. 121. 
[7] Rana P.B. Singh, Pravin S. Rana, Banares region: A spiritual and cultural guide (Varanasi, Indica Books, 2002), p. 20

[8] Alexander Cunningham, Ancient geography of India (Munshiram Manoharlal, 2002), pp. 132-136.

[9] B. Hans, Construction and reconstruction of sacred space in Varanasi, Numen, 43, 1996, 32-55.

[10] Sukumari Bhattacharji, Legends of devi (Calcutta, Orient Longman Limited, 1995), p. 56.

[11] Diana L. Eck, Banaras, city of light (Columbia University Press, 1982), p. 217.

[12] Niels Gutschow, Vārānasīi/Benares: The centre of Hinduism? A discussion of the meaning of "place" and space, Erdkunde, 48 (3), 1994, 194-209.

[13] Bansal Sunita Pant, Hindu pilgrimage: A journey through the holy places of Hindus all over India (Pustak Mahal, 2008), p. 35.

[14] Wilder-Smith, E. Schwartz and M. Shaw, Travel medicine tales behind the science (UK, Elsevier Linacre House, 2007), p. 273.

[15] Shobhna Gupta, Monuments of India (New Delhi, Har-Anand Publications, 2003), p. 11.

[16] V.S. Bhaskar, Faith and philosophy of Buddhism (Delhi, Kalpaz Publications, 2009), p. 169.

[17] W. Joanna, Sarnath gupta steles of the Buddha's life, Ars Orientalis, 10, 1975, 171-192.

[18] V.S. Bhaskar, Faith and philosophy of Buddhism (Delhi, Kalpaz Publications, 2009), p. 170.

[19] W. Joanna, (1975), pp. 177-184.

[20] L. M. Singhvi, Jain temples in India and around the world, (Himalayan Publishers, 2002), p. 42.

[21] Bharat S. Shah, An introduction to Jainism (New York, Setubandh Publications, 2002), p. 108.

[22] Jolie M.F. Wood, Contentious politics and civil society in Varanasi (Anthem Press, 2011), p. 9. 